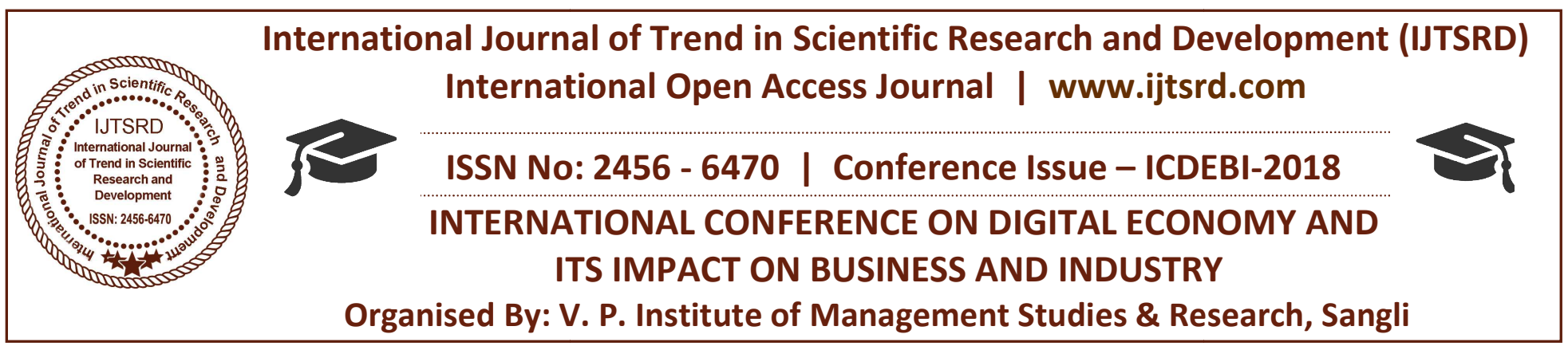

\title{
Information Technology and Indian Agriculture
}

\author{
Mylavarapu Monika Jahnavi
}

Assistant Professor, Chhatrapati Shahu Institute of Business Education and Research, Kolhapur Affiliated to Shivaji University, Kolhapur, Maharashtra, India

\begin{abstract}
Development of technology has opened new opportunities and dimensions for the agriculture sector in India. This technological advancement has enabled the country to shift from a period of traditional subsistence farming to an era of hi-tech commercial farming. India today makes use of technology at every stage of agriculture right from production and processing till marketing. In spite of this, there still remain challenges in its complete adoption by small and marginal farmers which if suitably addressed could lead to the rapid growth of the primary sector in the future years.
\end{abstract}

KEYWORDS: Information technology, agriculture, hi-tech, farmers

\section{INTRODUCTION}

Technology has changed our lives forever and for the best. Through its influence in different aspects of human life such as medicine, communication, education and transportation among others, life has become easy and comfortable for people. Similarly, technology has also had a huge transformational impact on agriculture in the Indian society. The 1965 green revolution in India brought about a major technological breakthrough, thus creating a longlasting impact on the nation's primary sector.

With 54.6\% (census 2011) of India's population engaged in agriculture and allied sectors (horticulture, floriculture, sericulture, and livestock, bee keeping and fishing) and with $17.4 \%$ (2016-17) contribution to the country's gross value added, the sector is an indispensable part of Indian economy. (Department of Agriculture, 2017). Productivity of certain agricultural items has shown a rising trend over the years and today, India ranks first in the production of cotton, jute, pulses and milk and second in the production of wheat, fruits and vegetables. This achievement has been possible due to the adoption of new technologies leading to higher crop yields, efficient utilisation of available inputs and crop diversification patterns. (Ministry of Commerce \& Industry, n.d.) (Ministry of Commerce \& Industry, n.d.) (FAO, n.d.) (India, 2017)

\section{BENEFITS OF INFORMATION TECHNOLOGY (IT) IN AGRICULTURE}

Providing food security is a critical issue for countries around the world, India being no exception. With India's population estimated to reach 1.5 billion by the year 2030, ensuring an increase in productivity becomes extremely important to tackle the problem of food security. The rapid adoption of advanced technologies in agriculture right from sowing of seeds till selling of the final product will not only help deal with food insecurity but also increase efficiency, production and income levels. (India's population to surpass China's around 2024, earlier than thought: UN, 2017) (WHAT WE DO, n.d.)

Information technology has a huge role to play in various levels of agriculture. Right from the selection of the seed till the time the final produce is marketed, technology ensures that no losses are faced by the producer during the pre and post-harvest period and those superior quality products reach consumers at reasonable prices.

Technology in agriculture can be used as a direct means for improving the productivity of agriculture and indirectly for helping farmers take more informed decisions regarding the production techniques, 
appropriate time for production and harvest and the market price of the final produce. Technology, thus, allows the farmers to take well informed and valuable decisions which consequently have a positive impact on the way activities in agriculture and its allied sectors are performed. (Milovanović, 2014)

From initially being confined to the use of traditional technologies where food was grown by farmers for their own subsistence, India later entered into the era of Green revolution. During this phase, through breeding programs and use of biotechnology, new and high yielding varieties of plants and animals were generated and farmers began using machineries, chemicals, fertilisers and pesticides on a large scale. This led to a shift in farming practices from subsistence to commercial farming. Presently, India is in the phase of high-tech agriculture where machinery is largely being used, infrastructural facilities such as warehouses and cold storages are being built and where the biotechnology sector is rapidly growing, thus, strengthening the country's agricultural segment. There is also a growth in the use of many modern techniques such as genetic engineering, soil, water and pest management and greenhouse technology. (Pandey, 2007)

Various production technologies include soil
management, water management, agriculture engineering, disease and pest management, greenhouse technology and use of genetic engineering among others. Processing technologies consist of freezing, pasteurisation, irradiation and heat processing. While, there has been an introduction of marketing portals such as AGMARKNET and eNAM at the marketing level.

Soil management includes the manufacture and use of products that improve availability of missing nutrients to soil. Water management on the other hand includes water harvesting and the use of micro irrigation systems such as drip and sprinkler irrigation which is cost effective, ensures efficient use and uniform distribution of water. Genetic engineering leads to the introduction or change of genes in crops making them resistant to diseases, drought and extreme weather situations.

The processing method of freezing is used for the preservation of nutritional value, taste and texture of food thus retarding microbial growth and delaying the chemical changes in food and hence its spoilage. While, irradiation is the application of ionizing radiations to food improving the safety and extending the shelf life of food and also eliminating the attack by microorganism and insects.

Government portals such AGMARKNET provides various stakeholders with electronic connectivity to the nation's wholesale markets by collecting and analysing the available market information. e-NAM, on the other hand is an electronic trading portal that brings together existing mandis thus creating a unified national market for various agricultural commodities. The growing smart phone penetration has enabled the launch of various farmer-oriented initiatives such as Mahindra's digital platform offering farmers with crucial farm related information and the $24 \times 7$ multilingual advisory platforms called MyAgriGuru. This application offers essential information such as weather forecasts, data and access to mandi price charts. The farmers can also interact with agricultural experts in case of doubts. (About Us, n.d.) (About NAM, n.d.) (Pandey, 2007) (Radiation technologies for the prevention of food loss, 2018) (Freezing and Food Safety, 2013) (Sharma, 2018)

Thus, the use of farmer friendly and inexpensive technologies in agriculture has not only brought changes in the production patterns of agricultural crops and increased the quantities of food but also made agriculture a production-cum-profit-oriented, risk reducing, employment generating and exportoriented sector.

\section{ISSUES RELATED TO THE USE OF INFORMATION TECHNOLOGY (IT) IN AGRICULTURE}

Use of information technology has enabled a large number of technological advancements within the primary sector. However, there are few issues associated with the use of IT in agriculture.

The number of small farmers in India is very large and so are the numbers of small land holdings. This makes it difficult to earn economic value through the use of machineries suitable only for large land holdings. Hence, various efforts are required to undertake research and development (R\&D) activities by the government and private players, for developing technologies that are suitable for the small and marginal land holdings of farmers.

Many villages in India lack internet connectivity thus hindering the practical application of IT in agriculture. This issue is being tackled by setting up mobile services and information kiosks by private players. Low literacy levels and lack of skills is yet another issue that hampers the use of various available farmer 
friendly applications. Hence, educational and training programmes are required for these people which will lead to growing adoption of computer technology and prepare the agriculture sector for future challenges.

Low availability and at times non-availability of basic infrastructure support system like roads, railways, water and electricity is yet another obstruction in the application of technologies in the agricultural sector. This requires efforts to be made through publicprivate partnership mode which will help in the development of infrastructural facilities and take the agricultural sector forward. (Pandey, 2007)

\section{CONCLUSION}

Dynamism and strength of technology is the backbone of agriculture. Technology opens the doors to socioeconomic development by creating various opportunities for all those involved in it. Its use leads to improved quality of food products, increased domestic consumption and economic growth through the exports of high-quality value-added products.

Technology has indeed opened new opportunities and dimensions for innovations in the agriculture sector enabling its rapid growth and development. The large number of technological advancements happening within the sector will lead to the sector's growth in the future years. However, there are also a number of issues associated with the use of technology in agriculture which need to be suitably addressed/via government support, through public-private partnerships in various technology-oriented projects and efforts to improve literacy and skill development for those in the agriculture sector.

\section{REFERENCES}

1. About NAM. (n.d.). Retrieved from Department of Agriculture, Cooperation \& Farmers' Welfare, Ministry of Agriculture and Farmers' Welfare, Government of India: https://enam.gov.in/NAM/home/about_nam.html\#

2. About Us. (n.d.). Retrieved from AGMARKNET: http://agmarknet.gov.in/OtherPages/aboutus.aspx

3. Department of Agriculture, C. \&. (2017). ANNUAL REPORT 2017-18. New Delhi: Government of India.

4. FAO. (n.d.). FAO in India. Retrieved from Food and Agriculture Organisation of the United Nations: $\quad$ http://www.fao.org/india/fao-inindia/india-at-a-glance/en/

5. Freezing and Food Safety. (2013, June 15). Retrieved from United States Department of Agriculture, Food Safety and Inspection Service: https://www.fsis.usda.gov/wps/portal/fsis/topics/f ood-safety-education/get-answers/food-safetyfact-sheets/safe-food-handling/freezing-and-foodsafety/CT_Index

6. India, G. o. (2017, March 09). India is the largest cotton producing and second largest cotton exporting country. Retrieved from Press Information Bureau, Government of India: http://pib.nic.in/newsite/mberel.aspx?relid=15908 2

7. India's population to surpass China's around 2024, earlier than thought: UN. (2017, June 21). Retrieved from live mint: https://www.livemint.com/Politics/xg5PjRFTNH YKg1AUhBVa6M/Indias-population-to-surpassChinas-around-2024-United-Na.html

8. Milovanović, S. (2014). THE ROLE AND POTENTIAL OF INFORMATION TECHNOLOGY IN AGRICULTURAL IMPROVEMENT. Economics of Agriculture, 471-485.

9. Ministry of Commerce \& Industry, G. o. (n.d.). FRESH FRUITS \& VEGETABLES. Retrieved from Agricultural \& Processed Food Products Export Ific Development Authority: http://apeda.gov.in/apedawebsite/six_head_produc t/FFV.htm

10. Ministry of Commerce \& Industry, G. o. (n.d.). WHEAT. Retrieved from Agricultural \& Processed Food Products Export Development Authority:

http://apeda.gov.in/apedawebsite/SubHead_Produ cts/Wheat.htm

11. Pandey, T. (2007). Indian Agriculture - Role of Technology. In N. J. Rao, \& A. S. Sisodiya, Agribusiness Transforming Indian Agriculture (pp. 55-71). Hyderabad: The Icfai University Press.

12. Radiation technologies for the prevention of food loss. (2018, March 07). Retrieved from Press Information Bureau, Government of India, Department of Atomic Energy: http://pib.nic.in/newsite/PrintRelease.aspx?relid=1 77097

13. Sharma, A. (2018, March). Technology Integration. Agriculture Today.

14. WHAT WE DO. (n.d.). Retrieved from Food And Agriculture Organisation of the United Nations: http://www.fao.org/about/what-we-do/en/ 